\section{LISTS OF REFERENCES.}

By Cuthbert E. A. Clayton, LIBRARIAN TO THE MANCHESTER MEDICAL SOCIETY ; MEMBER OF THE LIBRARY ASSOCIATION : IIATELY ASSISTANT IN THE LIBRARY O
THE ROYAL MEDICAL AND CHIRURGICAL SOCIETY OF LONDON.

-Mx work during the last few years has brought me so frequently into contact with compilers of medical bibliographies that I have been impressed with the need of some notes dealing with the subject.

With the exception of a paper by Dr. A. E. Garrod in the St. Bartholomew's Hospital Journal, 1894-5, ii, 145, and another by the late Mr. J. B. Bailey in the BrITISH Medical Journal, 1895, i, 875, very little has been written on the subject in England.

When one considers the appalling waste of time caused by incorrect and imperfect references, it will be evident that any suggestions tending to redure them to a minimum must be of service.

The making of a bibliography naturally falls into three divisions :

\section{A. Collection of material. \\ B. Arrangement. \\ C. Details of Construction.}

\section{A.-Collection of Material.}

This is more a matter of time than of difficulty. In the first place, the Index Catalogue of the Library of the SurgeonGeneral's Office, United States Army, must be consulted. This is an author and subject catalogue alphabetically arranged, and published annually ; monographs are entered twice, (1) under author's name, and (2) under subject; articles in periodical publications under the subject onlyfor example :

BENZINE.

See, also, Benzol.

JuNGFLEISCH (E.). (1) Recherches sur les dérivés chlorés de la benzine. (2) Propriétés optiques des cristaux. $4^{\circ}$ Paris, 1868.

BENECH. Sur l'action physiologique de la benzine, Compt. rend. Soc. de biol., 1878, Par. 1880, 6 s., v, 353-355. LANGDON (F. W.). Benzin as a parasiticide, Cincin. Lancet-Clinic, 1891, n.s. xxvi, 167-169.

The monograph by Jungfleisch is repeated under the author's name; the articles by Benech and Langdon are not.

The first series of the Surgeon-General's Catalogue, as it is familiarly called, consists of sixteen volumes, the date of the last volume being 1895 ; the second series has reached vol. x, 1905, M- Mnikhovski. Owing to the alphabetical arrangement, references cannot be obtained to authors or subjects after "Mnikhovski" later than those in the volumes of the first series containing the particular authors and subjects.

However, the difficulty is obviated by having recourse to the Index Medicus. This, also an American publication, is issued in simply-classified monthly parts, welded together by an excellent index at the end of each year.

The method of working the Index Medicus with the Surgeon-General's Catalogue is as follows: Let us suppose that we are compiling a bibliography on naevi. The last collection of references was in the Surgcon-General's Cataiogue, 1st Ser., 1888, ix, and all we have to do to bring this list to date is to commence with the volume of the Index Medicus for 1888.

For more special lists of referenc's there are several most useful compilations, such as Schmidt's Jahrbiicher der in- und ausländischen gesammten Medicin, Jahresbericht über die Fortschitte der Tier-Chemie, Jahresbericht über die Leistungen und Fortschritte im Gebiete der Ophthalmologie, etc.

The correctness of the references in the publications referred to may be relied upon, but if any be taken from actual articles they must be verified. To perpetrate an error by giving an incorrect reference is serious enough; it is almost criminal to perpetuate one.

\section{B.-Arrangement.}

This depends much upon the particular purpose for which the bibliography is intended; I think the enumeration of the various forms will be quite sufficient. A list may be arranged either, $(a)$ alphabetically according to names of authors, or (b) chronologically, or (c) classified if of great length.
C.-Details of Construction.

The following points must be carefully observed :

1. In every case the initials of an author should be given. If an author bear a hyphened name, or is known by his last christian name and surname, it should be placed under the last name-for example, John Bond Smith or Bond-Smith as follows: Smith (J. Bond or Bond-), never Bond. Smith (J.).

2. The name of the periodical must be so abbreviated that no doubt as to its nationality is possible. I think the abbreviations used in the Surgeon-General's Catalogue might be universally adopted.

3. References to papers should contain date, volume, and page; not the dates of the weekly or monthly parts for example, British Medical Journal, 1906, i, 173.

\section{THE MOTOR CAR REPORT.}

THE Royal Commission on Motor Cars, which was appointed to report upon the working of the Motor Car Acts of 1896 and 1903, the amendments desirable in them, the alleged injury to the roads, and other cognate matter, has issued its report.

The recommendations and the grounds upon which they are based are eminently sensible, and may be expected to be enacted when the renewal of the present Act comes up for consideration.

The question which is of perhaps the greatest interest is that of the speed limit; at present it is twenty miles an hour, but the Commission reports against the imposition of a speed limit except in places marked by a danger sign. The chief reason given for this perhaps rather unexpected conclusion is that in practice it has proved to be no protection to the public, but rather the contrary. There is a stringent clause in the existing Act against dangerous driving, and this, it is recommended, should be made yet more stringent. But this clause has been rendered practically inoperative by the police having devoted themselves almost entirely to catching, by means of police traps, persons offending against the speedlimit clause, and for that purpose selecting the most open, straight, and safe roads as being the places where even the most careful of motorists may be tempted to exceed the limit. Granting that police timing is accurate, and that the police are not tempted to stretch a point to get a "bag," two assumptions by no means certainly correct, the harm done by exceeding the limit in the safest pieces of road to be found in the district and the danger to the public are very small. But, as pointed out by the Commissioners, driving at or a little within the speed limit may in very many places be exceedingly dangerous; the ease of proof as to speed and the comparative difficulty of proof of dangerous driving have led the police to neglect the latter. We only know of one dangerous piece of road where police traps have ever been set; a considerable number of convictions have been obtained, but they have all been on the question of speed pure and simple. The only accident which has, so far as we know, happened in this place was caused by a motor which was being driven well below the speed limit, but presumably with insufficient care. This may serve yet further to illustrate the futility of prosecutions merely for exceeding the speed limit to the neglect of prosecutions for careless driving. Further the present speed limit is one that the more cautious of drivers are always approximating or reaching; if there is to be a speed limit at all it should be one that is not close upon the speed at which every one runs under safe conditions. In a singularly illogical paragraph appended to the report two of the Commissioners dissent from the abolition of the speed limit. Though one of them is the Commissioner of Police for the Metropolis, they actually suggest that the law be retained, but that it should not be enforced except " under reasonable conditions"!

To the suggestion that there should be a speed limit, but that army motor cars and those used by medical men for professional purposes be exempted, the Commissioners do not assent, except possibly in areas scheduled under the Manœuvres Act, 1901, and only for the period of manœuvres. A speed limit of twelve miles an hour is, however, recommended in all places marked by danger triangles; in large towns, and in villages and small towns where adopted by the local authorities. This 